\title{
DOI https://doi.org/10.30525/978-9934-26-041-4-106
}

\section{ВЗАСМОЗВ'ЯЗОК ХІМІЧНИХ НАУКОВИХ ГАЛУЗЕЙ З ХІМІЧНИМИ НАВЧАЛЬНИМИ ДИСЦИПЛІНАМИ}

\author{
Філіппова Л. В. \\ кандидат хімічних наук, доцент, \\ доиент кафедри медичної та загальної хімії \\ Національний медичний університет імені О. О. Богомольия \\ м. Київ, Украӥна
}

Виклики, що постають перед вищою фармацевтичною освітою України на сучасному етапі, актуалізують проблему дослідження стану й перспектив іï розвитку 3 метою розроблення відповідної стратегії підготовки фармацевтів. Необхідність такої стратегії продиктована вимогами суспільства і держави до підготовки конкурентоспроможних, мобільних, компетентних спеціалістів із фармації.

Суттєвий внесок у розроблення різних аспектів розвитку фармацевтичної освіти здійснили І. Зупанець, З. Мнушко, В. Черних (підготовка кадрів для фармацевтичної галузі), Котвицька, I. Ніженковська (напрями перебудови фармацевтичної науки), І. Булах, Л. Коновалова (системи обліку й основи економіки у фармації), Т. Рева (впровадження компетентнісного підходу ) та інші.

Зважаючи, що цільовою настановою методики навчання хімічних дисциплін, $\epsilon$ їх професійна орієнтованість, в рамках досліджуваної нами проблеми варто насамперед зосередити увагу на особливостях функціонування фармацевтичної галузі в нашій державі $[1,2]$. Розвиток національної вищої фармацевтичної освіти супроводжується актуальними вимогами громадян, суспільства й держави до підготовки конкурентоспроможних на ринку праці спеціалістів із фармації, забезпеченні доступної та ефективної фармакотерапії і профілактики захворювань населення.

Насамперед, Україна має потужну фармацевтичну промисловість, яка відповідає стандартам належної виробничої практики: за даними дослідження ринку «PharmXplorer»/»Фармстандарт» компанії «Proxima Research», на сучасному етапі частка реалізованих упаковок ліків українського виробництва у загальному обсязі ринку в натуральному вираженні становить близько $80 \%$, а у грошовому - близько $40 \%$, при 
цьому середньозважена вартість однієї упаковки вітчизняного препарату майже у п'ять разів нижча, ніж зарубіжного [1].

В Україні 112 підприємств мають державну ліцензію на виробництво лікарських засобів (ЛЗ), серед них такі потужні: АТ «Фармак», ФК «Здоров'я», ФФ «Дарниця», АТ «Лекхім Харків», ПАТ «Хімфармзавод «Червона зірка»«, ТОВ «Фармекс Груп», ТОВ «Валартин Фарм», «Бентокрим», ТОВ «Київветзавод», НВЦ «Борщагівський ХФЗ» та інші. У фармацевтичному секторі України працює близько 400 ти с. осіб; на початок 2016-2017 н. р. на факультетах фармацевтичного профілю навчалося майже 30 ти с. студентів [3]. Фармацевтичними підприємствами України натепер виробляється понад 12 тис. найменувань ЛЗ.

Питання досягнення якісної фармацевтичної освіти традиційно знаходяться під пильною увагою однієї із найбільш представницьких фармацевтичних організацій FIP. В рамках FIP існує окрема секція секція академічної фармації, основна увага якої зосереджена на підтримці та розвитку фармацевтичної освіти, поширені педагогічного досвіду, впровадженні новітніх освітніх технологій. Ці питання традиційно стоять й у порядку денному на 75-му Міжнародному конгресі Міжнародної Фармацевтичної Федерації (FIP) 3 фармації i фармацевтичних наук [4] та на VIII Національному з'їзді фармацевтів України [3].

Практично всі напрямки фармацевтичної наукової діяльності FIP тісно пов'язані так чи інакше 3 хімічними науковими галузями та хімічними навчальними дисциплінами, що вивчаються майбутніми фармацевтами в ЗВО. Так, аналітичні дослідження і фармацевтична якість, відкриття, розробка, виробництво ЛЗ, контроль якості пов'язані 3 аналітичною, токсикологічною та медичною хімією та проведенням клінічних випробувань. Безпечність та клінічна ефективність ЛЗ залежать від визначальною мірою від їх складу, тому передбачають знання неорганічної, органічної, аналітичної та колоїдної хімії. Наявність зміщення від розробки низькомолекулярних до біопрепаратів включно 3 вакцинами та білковими препаратами, посилює значення знань біоорганічної хімії. Продукти рослинного та тваринного походження мають надто складну структуру, що доволі часто стає перепоною для контролю їх якості, тому виникає потреба інтеграції традиційних та нетрадиційних ЛЗ.

Навіть регуляторна наукова діяльність, яка головною метою проголошує розвиток i формування науки майбутнього, особливий наголос робить на таких дослідженнях: часу розчинення препарату та його виведення, системі класифікації біопрепаратів, визначенні біоеквівалентності, проведенні клінічно пов’язаних досліджень. 
Зазначимо, що перспективи розвитку національної ВФО полягають у розв'язанні актуальних завдань підготовки майбутнього фахівця фармацевтичного сектора галузі охорони здоров'я України, серед яких важливими є: серед актуальних проблем підготовки майбутніх провізорів в Україні $є$ налагодження партнерства між складовими фармацевтичної галузі - освітою, наукою, промисловістю, аптечною мережею, закладами 3 контролю якості фармацевтичного забезпечення населення; удосконалення змісту освіти провізорів 3 урахуванням розбудови вітчизняного фармацевтичного виробництва лікарських засобів i медичного обладнання задля подолання імпортозалежності вітчизняного ринку лікарських засобів, забезпечення розвитку клінічного напряму у системі підготовки провізорів загального профілю для підвищення якості медикаментозної терапії та проведення фармацевтичної опіки GPP, що $\epsilon$ особливо затребуваним при запровадженні страхової медицини

При побудові методики професійно орієнтованого навчання хімічних дисциплін мають бути враховані: тенденції у світовій та вітчизняній фармацевтичній науці та практиці, зміна ролі фармацевтів в суспільстві (орієнтована на людей фармацевтична опіка, етичні проблеми, нові послуги, співпраця), національні та регіональні особливості формування фармацевтичного сектора галузі охорони здоров’я.

\section{Література:}

1. Філіппова Л.В. Проблеми підготовки майбутніх фахівців зі спеціальності «Фармація»/ Педагогічний процес: теорія $і$ практика, 2010, № 1, с. 170-176.

2. Філіппова Л.В. Діяльність фармацевтів в країнах $Є С$ та вимоги до їх підготовки з природничих дисциплін. Педагогічна освіта: теорія i практика: зб.наук.прачь Кам'янець-Подільського національного університету імені Івана Огієнка, Інститут педагогіки НАПН України, Вип. 26. С. 150-155.

3. Матеріали VIII Національного з'їду фармацевтів України, 13-16 вересня 2016 р., Харків (Україна). VIII Національний з’їзд фармацевтів України (Харків, 13-16 вер. 2016 р.): електрон. pecyp c. URL: http://www.isc.kharkov.com/uk/activity/news/ 2016 -09-15-14-42-17 (дата звернення: 16.10.2016). DOI: https://doi.org/10.15407/ugz2016.01.009).

4. 75-й Міжнародний конгрес Міжнародної Фармацевтичної Федерації (FIP) 3 фармації i фармацевтичних наук, 2015 p. URL: $\quad$ http://www.mospharma.org/ru/novosti-fip/75-mezhdunarodnyykongress/ (Дата звернення: 07.07.2017) 